http://dx.doi.org/10.11646/phytotaxa.156.3.4

\title{
Persicaria wugongshanensis (Polygonaceae: Persicarieae), an odoriferous and distylous new species from Jiangxi, eastern China
}

\section{BO LI}

Laboratory of Subtropical Biodiversity, Jiangxi Agricultural University, Nanchang, 330045, P. R. China; E-mail: hanbolijx@163.com.

\begin{abstract}
Persicaria wugongshanensis, a new species from Wugongshan Mountain, Jiangxi Province in eastern China, is described and illustrated. The new species is a distinctively odoriferous herb characterized by having glandular leaves and tepals, stout inflorescences, dimorphic flowers, extraordinarily long pedicels and densely pitted achenes. A morphological comparison among the new species and its putative relatives, P. hydropiper, P. japonica, P. jucunda and $P$. odorata, is presented. Comparative micromorphological characters of achenes, leaves, pollen grains and tepals of the new species and its closest relative $P$. odorata were also presented. Distyly and its ancillary dimorphism were observed and described. The somatic chromosome number $(2 n=20)$ and karyotype formula $(2 n=14 \mathrm{~m}+6 \mathrm{sm})$ of the new species were reported.
\end{abstract}

Key words: Chromosome number, distyly, endemic species, micromorphology, palynology, new species, Wugongshan Mountain

\section{Introduction}

Persicaria (Linnaeus 1753: 360) Miller (1754: without page) is formerly and popularly treated as synonym of Polygonum Linnaeus (1753: 359) in tribe Polygoneae (Polygonaceae). Though most taxonomists treated it as an infrageneric group of Polygonum (Meisner 1856, Bentham \& Hooker 1880, Dammer 1893, Steward 1930, Tutin et al. 1991, Li 1998, Li et al. 2003), the segregation of the two genera was strongly supported by several morphological and anatomical studies (Hedberg 1946, Haraldson 1978, Ronse Decraene \& Akeroyd 1988, Ronse Decraene et al. 2000), as well as by recent molecular studies (Kim \& Donoghue 2008a, Galasso et al. 2009, Sanchez et al. 2009, Burke et al. 2010, Sanchez et al. 2011). In this background, genera and tribes in the buckwheat family have been redefined, and Persicaria has been placed in the redefined tribe Persicarieae (Sanchez et al. 2011).

Persicaria comprises ca. 150 species and is distributed mainly in the northern temperate regions but extends into tropical regions (Brandbyge 1993). It includes prostrate or twining annual or perennial herbs, with manyflowered, spike-like or capitate inflorescences; 4-5-parted tepals with trifid venation; 4-8 stamens; pollen grains spheroidal (globose) and rough reticulate (often with tectate and pilate exine patterning) (Haraldson 1978, Ronse Decraene \& Akeroyd 1988, Brandbyge 1993).

During a field trip in September 2006 to the Wugongshan Mountain (Jiangxi Province, eastern China), a Polygonaceae species was collected and provisionally identified by me as Persicaria japonica (Meisner in de Candolle 1856 : 112) Nakai (in Ohki $1926: 51$ ), although I also noticed that the plant was remarkably different from $P$. japonica in a series of characters, such as its smell, annual habit, ovate to ovate-lanceolate leaf blades, densely pitted achenes and extraordinarily long pedicels. Subsequently, a dried specimen was sent to the expert Prof. Anjen Li (Institute of Botany, the Chinese Academy of Sciences): he suggested that it could represent a new species. Therefore, further investigations on ecology, floral and pollination biology were carried out from September 2009 to October 2011, and some individuals were cultivated in the South China Botanical Garden. Its status as a new species is thus fully confirmed, and the results are here reported. 
TABLE 3. Micromorphological comparison of Persicaria wugongshanensis and P. odorata.

\begin{tabular}{|c|c|c|}
\hline & P. wugongshanensis & P. odorata \\
\hline Achene surface & polygons surrounded by papillae & irregularly shallow reticulations \\
\hline Leaf epidermis & $\begin{array}{l}\text { upper leaf epidermis: epidermal cells polygonal, } \\
\text { stomatal apparatus paracytic lower leaf epidermis: } \\
\text { stomata size } 18.6(17.8-19.7) \mu \mathrm{m} \times 15.7(14.5-16.9) \\
\mu \mathrm{m} \text {, stomata density } 253 \text { number } / \mathrm{mm}^{2} \text {, guard cells } \\
\text { enclosed by } 2 \text { subsidiary cells mostly unequal in size } \\
\text { or sometimes } 3 \text { obviously unequal in size }\end{array}$ & $\begin{array}{l}\text { upper leaf epidermis: epidermal cells irregular, } \\
\text { stomatal apparatus anisocytic lower leaf } \\
\text { epidermis: stomata size } 25.4(23.1-26.8) \mu \mathrm{m} \times \\
19.6(18.2-20.9) \mu \mathrm{m} \text {, stomata density } 197 \\
\text { number } / \mathrm{mm}^{2} \text {, guard cells enclosed by } 2 \text { equal } \\
\text { subsidiary cells }\end{array}$ \\
\hline Pollen grains & $\begin{array}{l}\text { L-morph: lumen polygonal, uniform, } 7.64 \pm 0.351 \\
\mu \mathrm{m} \text { in size, } 7(6-8) \text { lumina across the diameter, } \\
\text { columellae in a lumen } 19(16-27) \mathrm{S}-\mathrm{morph} \text { : lumen } \\
\text { polygonal, uniform, } 10.21 \pm 0.512 \mu \mathrm{m} \text { in size, } 8(7- \\
\text { 9) lumina across the diameter, columellae in a lumen } \\
37(26-48)\end{array}$ & $\begin{array}{l}\text { L-morph: lumen irregular, unequal, } 8.42 \pm 0.719 \\
\mu \mathrm{m} \text {, in size, } 9(8-10) \text { lumina across the diameter, } \\
\text { columellae in a lumen } 24(15-31) \mathrm{S} \text {-morph: } \\
\text { lumen polygonal, unequal, } 11.63 \pm 0.823 \mu \mathrm{m} \text { in } \\
\text { size, } 5(6-7) \text { lumina across the diameter, } \\
\text { columellae in a lumen asymmetrical, } 33(24-45)\end{array}$ \\
\hline Tepal inner surface & $\begin{array}{l}\text { epidermal cells } 45-72 \mu \mathrm{m} \times 14-25 \mu \mathrm{m} \text {, longitudinal } \\
\text { direction with striate cuticles, anticlinal wall straight } \\
\text { or sinuolate, surface granular }\end{array}$ & $\begin{array}{l}\text { epidermal cells } 35-55 \mu \mathrm{m} \times 8-15 \mu \mathrm{m} \text {, } \\
\text { longitudinal direction with striate cuticles, } \\
\text { anticlinal wall sinuate, surface with intensely } \\
\text { developed ridge }\end{array}$ \\
\hline
\end{tabular}

\section{Diagnostic key of the taxa studied}

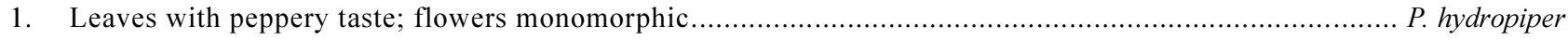

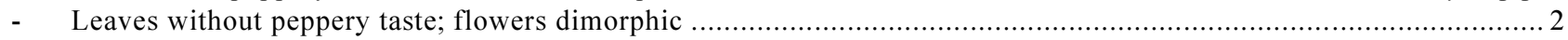

2. Inflorescences uninterrupted; flowers small; tepals without glandular dots ............................................................ P. jucunda

- Inflorescences usually interrupted at base; flowers large; tepals densely or sparsely golden punctuate ................................... 3

3. Plants without special odor; stems, leaves and ocreae densely or sparsely appressed............................................ P. japonica

- $\quad$ Plants intensely odoriferous (just like Houttuynia Thumb.); stems, leaves and ocreae glabrous or pubescent.............................. 4

4. Perennial herbs with developed rhizomes; leaf blades lanceolate or narrowly lanceolate, both surfaces glabrous or nearly glabrous; ocreae glabrous; achenes shiny, smooth ................................................................................................... odorata

- Annual herbs; leaf blades ovate or ovate-lanceolate, rarely broadly lanceolate, both surfaces sparsely pubescent; ocreae densely pubescent; achenes opaque, densely pitted............................................................................................... P. wugongshanensis

\section{Acknowledgements}

I am grateful to Prof. Anjen Li in for confirming the identification, to Prof. Qin-er Yang for critically read the manuscript, to Ms. Yunxiao Liu for the illustrations, to Ms. Xiao-Ying Hu for technical assistance with SEM observation, to Dr. Wengen Zhang and Mr. Zhuqiu Song for field assistances, and to Mr. Ken Harris and Mr. Yunhong Tan for providing images of $P$. odorata.

\section{References}

Bentham, G. \& Hooker, J.D. (1880) Genera Plantarum 3(1). Lovell Reeve \& Co., London, 459 pp.

Brandbyge, J. (1993) Polygonaceae. In: Kubitzki, K. \& Bittich, V. (eds.), The Families and Genera of Vascular Plants 2. Springer Verlag, Berlin, pp. 531-544.

Burke, J.M., Sanchez, A., Kron, K. \& Luckow, M. (2010) Placing the woody tropical genera of Polygonaceae: a hypothesis of character evolution and phylogeny. American Journal of Botany 97: 1377-1390. http://dx.doi.org/10.3732/ajb.1000022

Chen, M.L. \& Zhang, X.P. (2010) Distyly in Polygonum jucundum Meisn. (Polygonaceae). Plant Systematics and Evolution 288: $139-148$. http://dx.doi.org/10.1007/s00606-010-0318-x

Dammer, U. (1893) Polygonaceae. In: Engler, H. \& Prantl, K. (eds.), Die Natürlichen Pflanzenfamilien. (3rd edition) 1a. Engelmann Verlag, Leipzig, pp. 1-36.

De Candolle, A.P. (1856) Prodromus systematis naturalis regni vegetabilis, sive, Enumeratio contracta ordinum generum 
specierumque plantarum huc usque cognitarium, juxta methodi naturalis, normas digesta 14. Sumptibus Sociorum Treuttel et Würtz, Parisii, 706 pp.

Doida, Y. (1960) Cytological studies in Polygonum and related genera. The Botanical Magazine (Tokyo) 37: 337-340.

Galasso, G., Banfi, E., Mattia, F.D., Grassi, F., Sgorbati, S. \& Labra. M. (2009) Molecular phylogeny of Polygonum L. s.l. (Polygonoideae, Polygonaceae), focusing on European taxa: preliminary results and systematic considerations based on rbcL plastidial sequence data. Atti della Societa Italiana di Scienze Naturali e del Museo Civico di Storia Naturale di Milano 150: 113-148.

Gervais, C. (2000) Documentation chromosomique. Contribution no 1. Ludoviciana 29: 74-79.

Haraldson, K. (1978) Anatomy and taxonomy in Polygonaceae subfamily Polygonoideae Meisn. emend. Jaretzky. Symbolae Botanicae Upsalienses 22: 1-95.

Hedberg, O. (1946) Pollen morphology in the genus Polygonum L. s. l. and its taxonomical significance. Svensk Botanisk Tidskrift 40: 371-414.

Hong, S.P., Ronse Decraene, L.P. \& Smets, E. (1998) Systematic significance of tepal surface morphology in tribes Persicarieae and Polygoneae (Polygonaceae). Botanical Journal of the Linnean Society 127: 91-116. http://dx.doi.org/10.1111/j.1095-8339.1998.tb02091.x

Hou, Y.T. (2006) Systematic studies on the tribe Polygoneae of China. Shandong Normal University, Jinan, 290 pp.

IUCN (2012) IUCN Red List Categories and Criteria: Version 3.1. Prepared by the IUCN Species Survival Commission, Gland.

Iwatsubo, Y., Suzuki, T. \& Naruhashi, N. (2003) Polyploidy of Persicaria japonica (Polygonaceae) in Toyama Prefecture, central Japan. Journal of Phytogeography and Taxonomy 51: 59-61.

Kim, S.T. \& Donoghue, M.J. (2008a) Molecular phylogeny of Persicaria (Persicarieae, Polygonaceae). Systematic Botany 33: 77-86.

Kim, S.T. \& Donoghue, M.J. (2008b) Incongruence between cpDNA and nrITS trees indicates extensive hybridization within Eupersicaria (Polygonaceae). American Journal of Botany 95: 1122-1135. http://dx.doi.org/10.3732/ajb.0700008

Kim, S.T., Sultan, S.E. \& Donoghue, M.J. (2008) Allopolyploid speciation in Persicaria (Polygonaceae) insights from a lowcopy nuclear region. Proceedings of the National Academy of Sciences 105: 12370-12375. http://dx.doi.org/10.1073/pnas.0805141105

Li, A.J. (1998) Polygonaceae. In: Li, A.J. (ed.), Flora Reipublicae Popularis Sinicae 25(1). Science Press, Beijing, pp. 1-237.

Li, A.J., Bao, B.J., Grabovskaya-Borodina, A.E., Hong, S.P., McNeill, J., Mosyakin, S.L., Ohba, H. \& Park, C.W. (2003) Polygonaceae. In: Li, A.J. (ed.), Flora of China 5. Science Press, Beijing; Missouri Botanical Garden Press, St. Louis, pp. 277-350.

Li, M.X. \& Chen, R.Y. (1985) The standardization about the karyotype analysis. Journal of Wuhan Botanical Research 3: 297302.

Linnaeus, C. (1753) Species Plantarum 1. Laurentius Salvius, Stockholm, 560 pp.

Loureiro, J. (1790) Flora Cochinchinensis : sistens plantas in regno Cochinchina nascentes : quibus accedunt aliae observatae in Sinensi imperio, Africa orientali, Indiaeque locis variis : omnes dispositae secundum systema sexuale Linnaeanum 1. Typis, et expensis Academicis, Ulyssipone, $353 \mathrm{pp}$. http://dx.doi.org/10.5962/bhl.title.560

Löve, Á. \& Löve, D. (1956) Chromosomes and taxonomy of eastern North American Polygonum. Canadian Journal of Botany 34: 501-521. http://dx.doi.org/10.1139/b56-039

Meisner, C.F. (1826) Monographiae Generis Polygoni Prodromus. Sumtibus Auctoris, Typis A. Lador, Genevae, 110 pp.

Meisner, C.F. (1856) Polygonaceae. In: de Candolle, A. (ed.), Prodomus systematis naturalis regni vegetabilis 14. Masson, Paris, pp. 1-185.

Migo, H. (1939) Notes on the flora of South-eastern China, IV. The journal of the Shanghai Science Institute, Section III 4: $142-143$.

Miller, P. (1754) The gardener's dictionary, Abridged 4th edition 3. Printed for the Author, London, without pagination.

Nakata, M. \& Nagai, S. (1998) Chromosome numbers of some aquatic plants collected in Toyama Prefecture. Bulletin of the Botanic Gardens of Toyama 37: 1-6.

Nishihiro, J. \& Washitani, I. (1998) Patterns and consequences of self-pollen deposition on stigmas in heterostylous Persicaria japonica (Polygonaceae). American Journal of Botany 85: 352-359. http://dx.doi.org/10.2307/2446328

Ohki, K. (1926) Polygonaceae of the island Iki. The Botanical Magazine (Tokyo) 40: 48-58.

Probatova, N.S. (2000) Chromosome numbers in some plant species from the Razdolnaya (Suifun) river basin (Primorsky Territory). Botaničeskij Žhurnal (Moscow \& Leningrad) 85: 102-107.

Qaiser, M. (2005) Polygonaceae. In: Qaiser, M. (ed.), Flora of Pakistan 205. Missouri Botanical Garden Press, St. Louis, 190 pp.

Ronse Decraene, L.P. \& Akeroyd, J.R. (1988) Generic limits in Polygonum and related genera (Polygonaceae) on the basis of floral characters. Botanical Journal of the Linnean Society 98: 321-371.

http://dx.doi.org/10.1111/j.1095-8339.1988.tb01706.x 
Ronse Decraene, L.P., Hong, S.P. \& Smets, E. (2000) Systematic significance of fruit morphology and anatmy in tribes Persicarieae and Polygoneae (Polygonaceae). Botanical Journal of the Linnean Society 134: 301-337. http://dx.doi.org/10.1111/j.1095-8339.2000.tb02356.x

Sanchez, A., Schuster, T.M., Burke, J.M. \& Kron, K.A. (2011) Taxonomy of Polygonoideae (Polygonaceae): a new tribal classification. Taxon 60: 151-160.

Sanchez, A., Schuster, T.M. \& Kron, K.A. (2009) A large-scale phylogeny of Polygonaceae based on molecular data. International Journal of Plant Sciences 170: 1044-1055. http://dx.doi.org/10.1086/605121

Soják, J. (1974) Bemerkungen zur Gattung Truellum Houtt. (Polygonaceae) [Remarks on the genus Truellum Houtt. (Polygonaceae)]. Preslia 46: 139-156.

Spach, E. (1841) Histoire naturelle des végétaux: Phanérogames 10. Librairie encyclopédique de Roret, Paris, 572 pp.

Steward, A.N. (1930) The Polygoneae of Eastern Asia. Contributions from the Gray Herbarium of Harvard University 5: 1129.

Thiers, B. (2011) Index Herbariorum: A global directory of public herbaria and associated staff. New York Botanical Garden's Virtual Herbarium. Available from http://sweetgum.nybg.org/ih/ (accessed: 30 September 2013).

Thunberg, C.P. (1783) Beskrifning på ett nytt japanskt ört-genus, kalladt Houtuynia cordata. In: Kongl. Vetenskaps Academiens Nya Handlingar 4. L.L. Grefing, Stockholm, pp. 149-152.

Tutin, T.G, Burges, N.A., Edmondson, J.R., Heywood, V.H., Moore, D.M., Valentine, D.H., Waiters, S.M. \& Webb, D.A. (1991) Polygonaceae. In: Tutin, T.G. (ed.), Flora Europaea (2nd edition) 1. Cambridge University Press, London, pp. 91108.

Wolf, S.J. \& McNeill, J. (1987) Cytotaxonomic studies on Polygonum section Polygonum (Polygonaceae) in eastern Canada and the adjacent United States. Canadian Journal of Botany 65: 647-652. http://dx.doi.org/10.1139/b87-085

Zhang, X.P. \& Zhou, Z.Z. (1998) A study on pollen morphology and its phylogeny of Polygonaceae in China. Press of University of Science and Technology of China, Hefei, $235 \mathrm{pp}$.

Zakirova, R.O. \& Nafanailova, I.I. (1990) Chromosome numbers in the members of some families of vascular plants in the flora of Kazakhstan. Botaničeskij Žhurnal (Moscow \& Leningrad) 75: 438-439. 